\title{
Arg913Gln variation of SLC12A3 gene is associated with diabetic nephropathy in type 2 diabetes and Gitelman syndrome: a systematic review
}

\author{
Eduardo De la Cruz-Cano ${ }^{1,2}$, Cristina del C. Jiménez-González', Vicente Morales-García' , Conny Pineda-Pérez³, \\ Juan G. Tejas-Juárez ${ }^{1}$, Francisco J. Rendón-Gandarilla ${ }^{5}$, Silvia Jiménez-Morales ${ }^{4}$ and José A. Díaz-Gandarilla ${ }^{*}$
}

\begin{abstract}
Background: Diabetic nephropathy is a global common cause of chronic kidney disease and end-stage renal disease. A lot of research has been conducted in biomedical sciences, which has enhanced understanding of the pathophysiology of diabetic nephropathy and has expanded the potential available therapies. An increasing number of evidence suggests that genetic alterations play a major role in development and progression of diabetic nephropathy. This systematic review was focused on searching an association between Arg913Gln variation in SLC12A3 gene with diabetic nephropathy in individuals with Type 2 Diabetes and Gitelman Syndrome.

Methods: An extensive systematic review of the literature was completed using PubMed, EBSCO and Cochrane Library, from their inception to January 2018. The PRISMA guidelines were followed and the search strategy ensured that all possible studies were identified to compile the review. Inclusion criteria for this review were: 1) Studies that analyzed the SLC12A3 gene in individuals with Type 2 Diabetes and Gitelman Syndrome. 2) Use of at least one analysis investigating the association between the Arg913GIn variation of SLC12A3 gene with diabetic nephropathy. 3) Use of a case-control or follow-up design. 4) Investigation of type 2 diabetes mellitus in individuals with Gitelman's syndrome, with a history of diabetic nephropathy.
\end{abstract}

Results: The included studies comprised 2106 individuals with diabetic nephropathy. This review shows a significant genetic association in most studies in the Arg913GIn variation of SLC12A3 gene with the diabetic nephropathy, pointing out that the mutations of this gene could be a key predictor of end-stage renal disease.

Conclusions: The results showed in this systematic review contribute to better understanding of the association between the Arg913Gln variation of SLC12A3 gene with the pathogenesis of diabetic nephropathy in individuals with T2DM and GS.

Keywords: Diabetic nephropathy, Type 2 diabetes mellitus, Gitelman syndrome, SLC12A3 gene

\section{Background}

Diabetic nephropathy (DN) is the most common cause of end-stage renal disease (ESRD) in most of the countries worldwide $[1,2]$. The increasing incidence of this condition has become a serious public health problem in terms of both mortality and medical costs [3-5]. Clinical findings of diabetic nephropathy include a decline in estimated glomerular filtration rate (eGFR) [6-8] as well

\footnotetext{
* Correspondence: diazgandarilla123@gmail.com

${ }^{1}$ División Académica Multidisciplinaria de Comalcalco, Universidad Juárez

Autónoma de Tabasco, C. P. 86650 Comalcalco, Tabasco, Mexico

Full list of author information is available at the end of the article
}

as a progressive increase in urinary albumin excretion $[9,10]$, associated with an increase in blood pressure and subsequent risk of renal failure [11, 12]. These pathophysiological findings have been related as a consequence of structural abnormalities linked with a rapid renal deterioration, including: a) decrease in the number and/or density of podocytes [13, 14], b) glomerular basement membrane thickening $[15,16], c)$ progressive expansion of mesangial matrix $[17,18], d$ ) tubulointerstitial fibrosis and overt proteinuria $[19,20]$, eventually a leading cause of glomerulosclerosis and end-stage renal disease [21, 22]. In

(c) The Author(s). 2019 Open Access This article is distributed under the terms of the Creative Commons Attribution 4.0 International License (http://creativecommons.org/licenses/by/4.0/), which permits unrestricted use, distribution, and reproduction in any medium, provided you give appropriate credit to the original author(s) and the source, provide a link to the Creative Commons license, and indicate if changes were made. The Creative Commons Public Domain Dedication waiver (http://creativecommons.org/publicdomain/zero/1.0/) applies to the data made available in this article, unless otherwise stated. 
this context, several epidemiological studies suggest that multiple genetic factors are involved in susceptibility of the pathogenesis of diabetic nephropathy, which has led to extensive research to identify the genes implicated in the development and progression of this condition [16, 23-25]; one of these genes is the solute carrier family 12 member 3 (SLC12A3) gene [16]. The SLC12A3 gene is located on chromosome 16q13 and is specifically expressed in the kidneys, where it encodes a thiazide-sensitive $\mathrm{Na}-\mathrm{Cl}$ co-transporter (NCC), which is the major salt reabsorption pathway in the distal convoluted tubule (DCT) and located just after the macula densa at the beginning of the aldosterone-sensitive nephron [26, 27]. The NCC is a protein with a molecular weight of $150 \mathrm{kDa}$ with approximately 1002 to 1028 amino acid residues. It is able to form dimers, and it is likely to work as a dimer [26, 27]. The NCC is glycosylated at two sites (N404 and N424) located in the long extracellular loop and it is the site of action of the diuretic thiazide that is frequently administered to patients with T2DM suffering from diabetic nephropathy (see Fig. 1). For a review see Gamba [27]. Furthermore, the inactivation of the $\mathrm{Na}-\mathrm{Cl}$ co-transporter (SLC12A3) gene is known for being responsible for Gitelman Syndrome (GS), an autosomal recessive renal tubular disorder characterized by hypokalaemia, marked metabolic alkalosis, hypomagnesemia, hypocalciuria, as well as renal potassium and magnesium wasting [30, 31]. Recently, more than 100 different mutations in this gene have been described in patients with GS, in whom a kidney dysfunction has also been linked with abnormalities in the glucose metabolism [30, 32, 33]. Unfortunately, the precise molecular mechanisms linking T2DM and GS are not well understood. However, dysfunction in NCC could be one of the main causes through which insulin resistance in T2DM-individuals leads to chronic hyperglycaemia state and consequently to diabetic nephropathy risk [32, 33]. This assumption is supported by: (a) it has been suggested that most of alterations in SLC12A3 gene are inactivating mutations that impair gene transcription or translation in patients with T2DM and GS [33, 34], (b) This mutational damage would lead to a truncated/alterated NCC cotransporter polypeptide with a loss function causing impaired reabsorption of sodium chloride, potassium and magnesium in the DCT (see Fig. 2) [38, 39], (c) both hypokalaemia as well as hypomagnaesemia have been related to cause insulin secretion abnormalities [33, 40]. Thus, the molecular alterations in this gene could be a key to explain the strong association in both disorders with diabetic nephropathy. That is the reason why

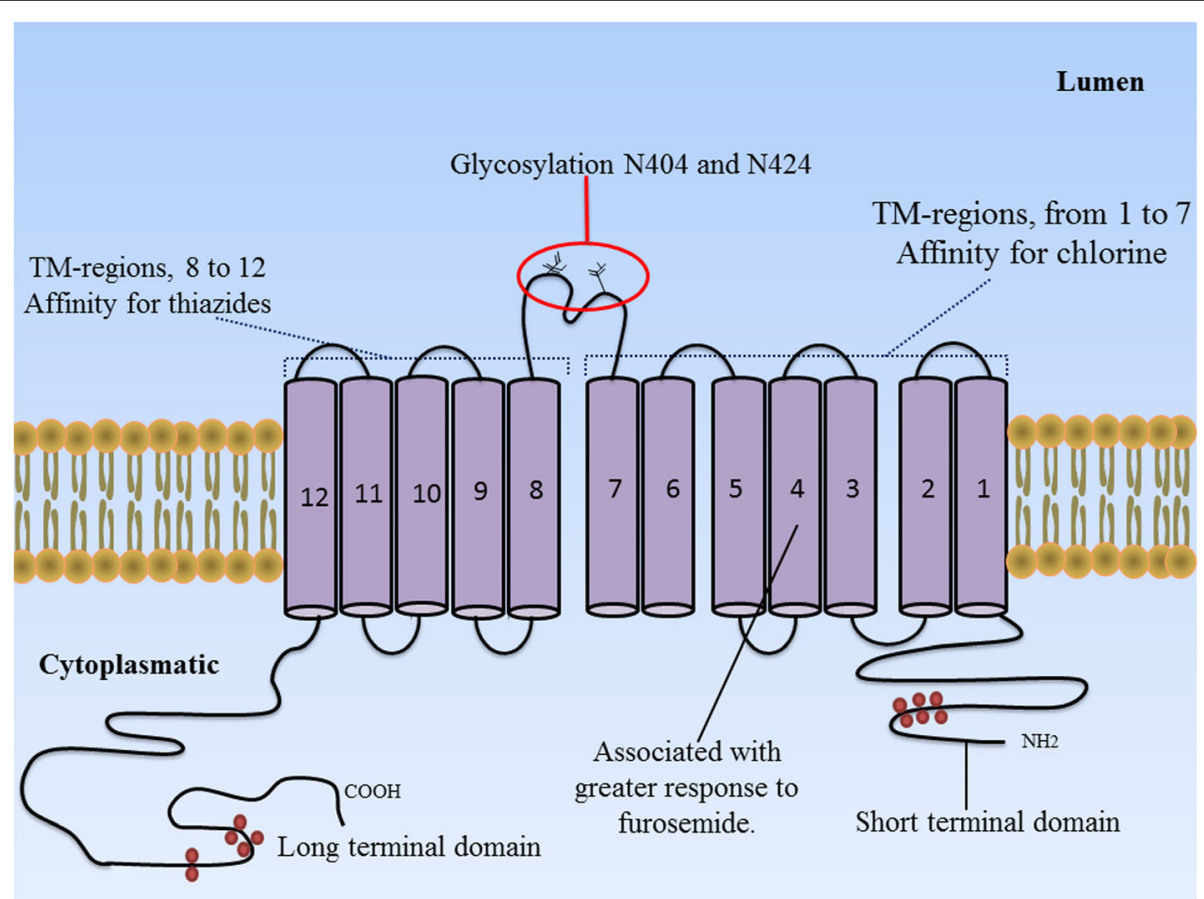

Fig. 1 Proposed topology of the thiazide-sensitive Na-Cl co-transporter. The NCC is a protein composed of a central hydrophobic domain containing 12 transmembrane regions (see from right to left) interconnected by six extracellular handles and five cytoplasmic handles. The glycosylation is present on the large extracellular loop between the 7th and 8th membrane-spanning segment, which is essential in trafficking proteins to the cell surface. Also, the central hydrophobic domain is flanked by a short amino-terminal domain $\left(\mathrm{NH}_{2}\right)$ and a long carboxylterminal domain $(\mathrm{COOH})$, which are located inside the cell [27, 28]. Figure adapted from Gamba G [29]. 

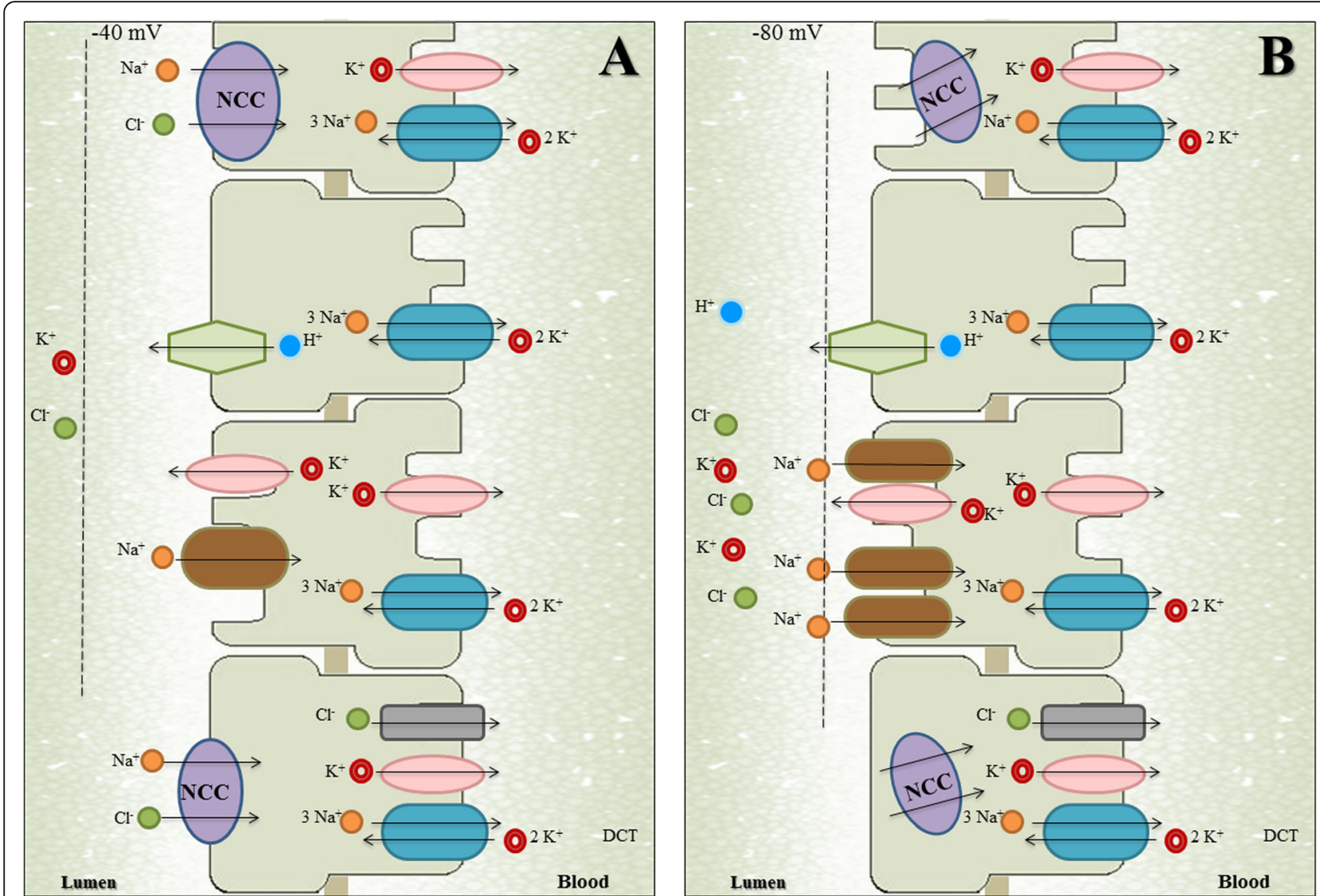

Fig. 2 a Normal dynamics of reabsorption in the distal nephron. Most of the $\mathrm{Na}^{+}$and $\mathrm{Cl}^{-}$reaching the distal nephron is reabsorbed by $\mathrm{NCC}$ in the distal convoluted tubule (DCT) and a smaller percentage is reabsorbed by ENaC in the connecting tubule (CNT) and cortical collecting duct (CCD). However, ENaC reabsorbs exclusively $\mathrm{Na}^{+}$without $\mathrm{Cl}^{-}$in an electrogenic way, which generates a transepithelial potential of $-40 \mathrm{mV}$. This negative potential in the tubular light favors the secretion of $\mathrm{K}^{+}$and others protons. $\mathbf{b}$ Abnormal dynamics of reabsorption in the distal nephron. In individuals with Gitelman syndrome or other salt-losing tubulopathies with DCT defects, the dysfunction in NCC (by inactivating mutations in SLC12A3 gene) leads to a greater arrival of $\mathrm{Na}^{+}$and $\mathrm{Cl}^{-}$to CNT/CCD, which favors $\mathrm{Na}^{+}$reabsorption mediated by ENaC. Thus, the increase in the electrogenic reabsorption of $\mathrm{Na}^{+}$increases the transepithelial potential and this produces greater tubular secretion of potassium and others protons (as magnesium and sodium) [35, 36]. Abbreviations: CLCNKB: chloride voltage-gated channel Kb; ENaC: epithelial sodium channel; NCC: thiazide-sensitive Na-Cl co-transporter; ROMK: renal outer medullary potassium channel. Figure adapted from Seyberth et al [37]

this systematic review was focused on identifying studies that associated the Arg913Gln variation of SLC12A3 gene with the diabetic nephropathy in T2DM and GS.

\section{PICOS question}

How the Arg913Gln variation of SLC12A3 gene influence in the pathophysiology of diabetic nephropathy in individuals with Type 2 Diabetes Mellitus and Gitelman syndrome?

\section{Type of studies}

Both, case-control and follow-up studies were included for this review.

\section{Methods}

\section{Literature search strategy}

An extensive systematic review of the literature was completed by searching three electronic databases (PubMed,
EBSCO and Cochrane Library) from their inception to January 2018 (Additional file 1). From 2407 studies found during the search, only thirteen studies met the inclusion criteria (see Fig. 3). Different combinations of the keywords "SLC12A3 gene AND diabetic nephropathy", "SLC12A3 gene AND type 2 diabetes mellitus", "SLC12A3 gene AND Gitelman Syndrome AND diabetic nephropathy"; "SLC12A3 gene AND Gitelman Syndrome AND type 2 diabetes mellitus" were used to screen for potentially relevant studies. The references of all included articles were also screened. The search strategy was conducted in accordance with the PRISMA guidelines (Additional file 2) [41]. The reasons for exclusion as well as the search terms used for PubMed, EBSCO and Cochrane Library databases are displayed in Fig. 3. The quantitative synthesis of the results from the included studies was not possible due to evident methodological 


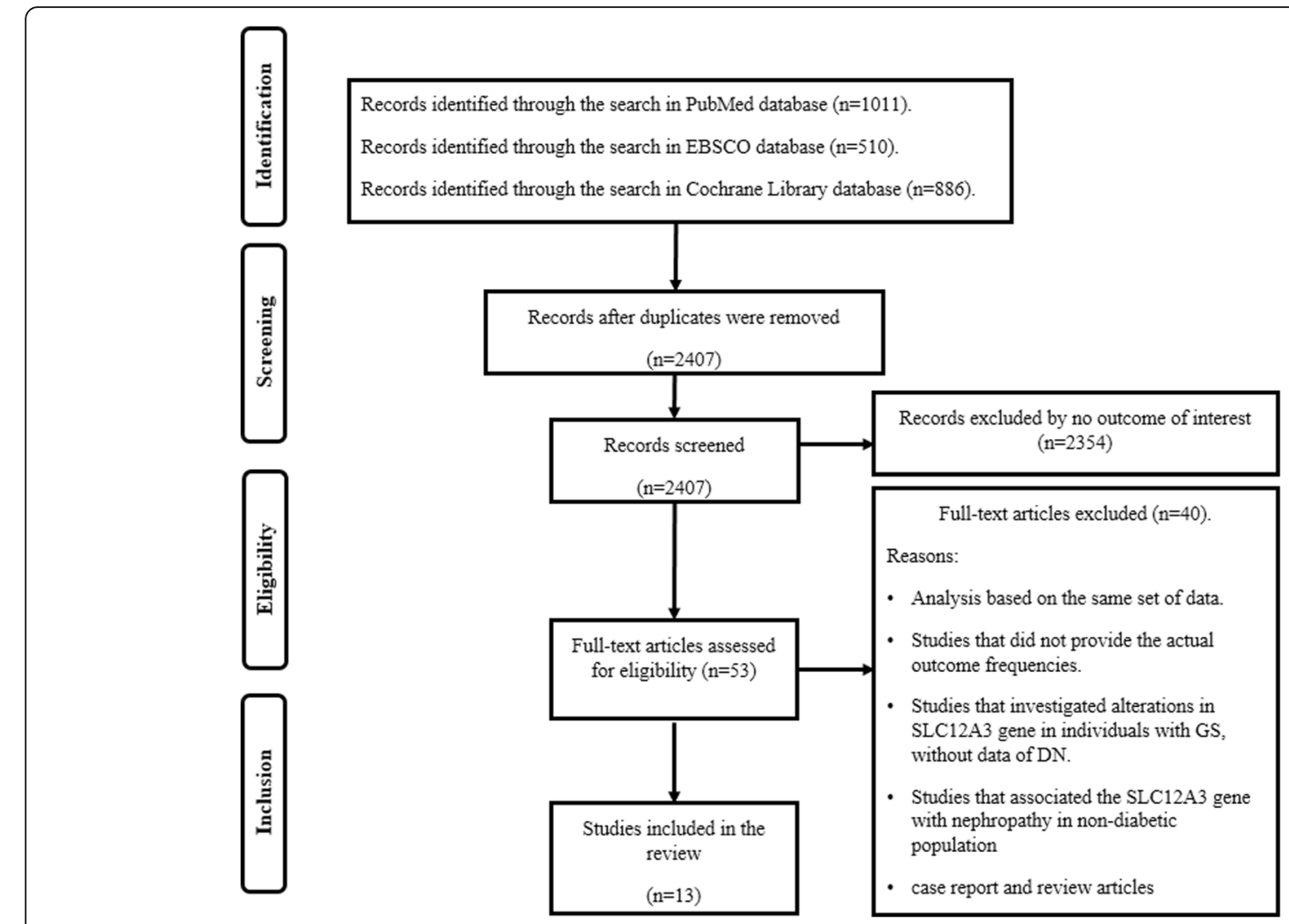

Fig. 3 Flow chart showing the search strategy and inclusion/exclusion criteria used in this systematic review

heterogeneity, therefore a meta-analysis was not considered.

\section{Inclusion and exclusion criteria}

A study was included in this systematic review only if it met all the following inclusion criteria: 1) Studies that analyzed the SLC12A3 gene in individuals with T2DM and/or GS. 2) Use of at least one analysis investigating the association between the Arg913Gln variation of SLC12A3 gene with diabetic nephropathy. 3) Use of a case-control or follow-up design; 4) Investigation of type 2 diabetes mellitus in individuals with Gitelman's syndrome, with a history of diabetic nephropathy and/or end-stage renal disease; 5) Inclusion of reports written only in English language. The analysis based on the same set of data were excluded. The studies that associated the SLC12A3 gene with nephropathy in non-diabetic population as well as studies that investigated alterations in this gene in individuals with Gitelman's syndrome, without data of diabetic nephropathy were not included. Duplicate publications and case reports, were also excluded. The Fig. 3 shows the study selection process.

\section{Data extraction}

Two investigators (E.D.C. and C.J.G.) extracted the data independently. For conflicting evaluations, an agreement was reached after a discussion. Briefly, for all studies, the following data were extracted from the original publications: first author, year of publication, study design, population analysed, number of patients included (only those that were diagnosed with type 2 diabetes) and control subjects, main characteristics of individuals, as well as main results of association with diabetic nephropathy for type 2 diabetes mellitus and Gitelman Syndrome.

\section{Descriptive synthesis \\ SLC12A3 gene in T2DM-individuals with diabetic nephropathy}

Nine case-control studies were found analyzing the SLC12A3 gene in T2DM-individuals (see Table 1). Kim et al [42], Zhao et al [47], Zhang et al [48] and Bodhini et al [46] analyzed Koreans, Chinese and Indians individuals. These studies reported that the minor allele 913Gln in the SLC12A3 gene was significantly associated with end-stage renal disease. Also, these studies concluded that this genetic variant could predict the risk of increase of albuminuria in individuals with T2DM [42, 46-48]. Also, Abu et al [43] and Nishiyama et al [45] analyzed Asian population (specifically Malaysians and Japanese individuals, respectively), in which it was reported that carriers of the Arg913Gln variation were linked with diabetic nephropathy as well as alterations in albumin 
Table 1 Evidence of studies that associated the SLC12A3 gene with diabetic nephropathy in T2DM

\begin{tabular}{|c|c|c|c|c|c|c|c|}
\hline \multirow{2}{*}{$\begin{array}{l}\text { Author } \\
\text { (year) }\end{array}$} & \multirow{2}{*}{$\begin{array}{l}\text { Study } \\
\text { design }\end{array}$} & \multirow[t]{2}{*}{ Country } & \multicolumn{2}{|c|}{ N Sample } & \multirow{2}{*}{$\begin{array}{l}\text { Characteristics of individuals with diabetic } \\
\text { nephropathy }\end{array}$} & \multirow{2}{*}{$\begin{array}{l}\text { Major } \\
\text { diagnosis }\end{array}$} & \multirow{2}{*}{$\begin{array}{l}\text { Main results of association with diabetic } \\
\text { nephropathy }\end{array}$} \\
\hline & & & Cases & Controls & & & \\
\hline $\begin{array}{l}\text { Tanaka } \\
\text { et al [23] } \\
\text { (2003) }\end{array}$ & $\begin{array}{l}\text { Case- } \\
\text { control }\end{array}$ & Japanese & 94 & 94 & $\begin{array}{l}\text { Female } n=31 \text {; Male } n=63 \text {; Duration of } \\
\text { diabetes } \pm \mathrm{SD} \text { (years })=18.6 \pm 9.7 ; \mathrm{HbA} 1 \mathrm{c} \\
(\%) \pm \mathrm{SD}=7.7 \pm 1.3 ; \mathrm{S}-\mathrm{Cr}(\mathrm{mg} / \mathrm{dl}) \pm \mathrm{SD}= \\
1.37 \pm 0.83\end{array}$ & DN & $\begin{array}{l}\text { In this study Tanaka and colleagues } \\
\text { reported that SLC12A3 -Arg913GIn } \\
\text { variation might reduce the risk to develop } \\
\text { diabetic nephropathy (OR = 2.53; Cl } 95 \%= \\
1.57-4.09 ; p=0.000087) \text {. }\end{array}$ \\
\hline
\end{tabular}

Kim et al Case- Koreans $177 \quad 184$

[42] (2006) control

$\mathrm{Ng}$ et al Case- American $295 \quad 174$

[24] (2008) control Caucasians

Abu et al Case- Malaysians $124 \quad 784$

[43] (2014) control
Female $n=72$; Male $n=105 ;$ Mean age \pm $\mathrm{SD}=61 \pm 9$

Duration of diabetes \pm SD (years) $=18 \pm 8$; $\mathrm{HbA} 1 \mathrm{c}(\%) \pm \mathrm{SD}=7.2 \pm 1.5 ; \mathrm{S}-\mathrm{Cr}(\mathrm{mg} / \mathrm{dl}) \pm$ $\mathrm{SD}=7.03 \pm 2.4$

Female $n=116$; Male $n=179$; Duration of $D N$ diabetes $\pm \mathrm{SD}$ (years) $=17 \pm 8 ; \mathrm{HbA} 1 \mathrm{c}$ (\%) $\pm \mathrm{SD}=8.0 \pm 1.6 ; \mathrm{S}-\mathrm{Cr}(\mathrm{mg} / \mathrm{dl}) \pm \mathrm{SD}=$ $7.03 \pm 2.4$; Cases with CRF/ESRD (\%) $=53.2$

Female $n=56$; Male $n=68$; Duration of diabetes $\pm \mathrm{SD}$ (years) $=13 \pm 8 ; \mathrm{HbA} 1 \mathrm{C}$ $(\mathrm{mmol} / \mathrm{mol}) \pm \mathrm{SD}=8.8 \pm 2.2 ; \mathrm{S}-\mathrm{Cr}(\mathrm{mg} /$ dl) $\pm \mathrm{SD}=2.23 \pm 1.94 ; \mathrm{GFR} \pm \mathrm{SD}(\mathrm{ml} / \mathrm{min} /$ 341.2

\begin{tabular}{|c|c|c|}
\hline $\begin{array}{l}\text { Yadav } \\
\text { et al [44] } \\
\text { (2014) }\end{array}$ & $\begin{array}{l}\text { Case- } \\
\text { control }\end{array}$ & Indians \\
\hline
\end{tabular}

Nishiyama Case- Japanese $71 \quad 193$ et al [45] control (2005)
Female $n=62$; Male $n=140$;Duration of diabetes \pm SD (years) $=13.81 \pm 7.01$; $(\mathrm{mg} / \mathrm{dl}) \pm \mathrm{SD}=1.55 \pm 0.97 ; \mathrm{FBS}(\mathrm{mg} / \mathrm{dL}) \pm$ $\mathrm{SD}=139 \pm 53$

Female $n=18$; Male $n=53$; Duration of diabetes $\pm \mathrm{SD}$ (years) $=8.5 \pm 0.9 ; \mathrm{HbA} 1 \mathrm{c}$ $(\mathrm{mmol} / \mathrm{mol}) \pm \mathrm{SD}=8.08 \pm 0.13$. $\mathrm{HbA} 1 \mathrm{c}(\mathrm{mmol} / \mathrm{mol}) \pm \mathrm{SD}=8.0 \pm 2.0 ; \mathrm{S}-\mathrm{Cr}$

DN $1.73 \mathrm{~m} 2)=59.8 \pm 35.5 ; \mathrm{ACR} \pm \mathrm{SD}=269.8 \pm$

DN/ESRD This study reported that the Arg913GIn variation of SLC12A3 gene is associated with ESRD resulting from diabetic nephropathy in Korean population. $(\mathrm{OR}=$ 2.30; $\mathrm{Cl} 95 \%=1.32-4.00 ; p=0.003)$.

In this study none of the SNPs showed any significant association with advanced diabetic nephropathy both in terms of allelic or genotypic distributions (OR = $1.213 ; 95 \% \mathrm{Cl}=0.775-1.897 ; p=0.397)$.

DN This study reported that SLC12A3 -Arg913GIn variation was associated with diabetic nephropathy $(\mathrm{OR}=0.547 ; 95 \%$ $\mathrm{Cl}=0.308-0.973 ; p=0.038)$ and $\mathrm{T} 2 \mathrm{DM}$ $(\mathrm{OR}=0.772 ; 95 \% \mathrm{Cl}=0.612-0.973 ; p=$ 0.028). In addition, Abu and colleagues indicated that the minor $913 \mathrm{Gln}$ allele in this gene could confer a protective effect in the DN.

This study reported significant differences in the Arg913GIn variation of SLC12A3 gene between diabetic subjects and controls $(P<0.03)$.

In this study it was reported that SLC12A3 -Arg913GIn variation was linked with albumin excretion $(\mathrm{OR}=0.09 ; 95 \% \mathrm{Cl}=$ $0.01-0.92 ; p=0.043$ ), and that the $+78 \mathrm{~A}$ allele could have a protective effect against the development of DN among this population.

In this study it was showed that the individuals carrying of the SLC12A3 -Arg913GIn variation had a significant association with $\mathrm{DN}(\mathrm{OR}=1.52 ; 95 \% \mathrm{Cl}=$ $1.06-2.18 ; p=0.020$ ).

diabetes $+\mathrm{SD}$ (years) $=19+8 ; \mathrm{HbA} 1 \mathrm{c}$ (\%) $\pm \mathrm{SD}=8.6 \pm 1.9 ; \mathrm{FBS}(\mathrm{mg} / \mathrm{dL}) \pm \mathrm{SD}=$ $160.3 \pm 73.9 ; \mathrm{S}-\mathrm{Cr}(\mathrm{mg} / \mathrm{dl}) \pm \mathrm{SD}=1.2 \pm 0.89$

Zhao et al Case- Chinese $163 \quad 96$

Clinical and sociodemographic DN characteristics were not reported because the full article was not found

This study concluded that Arg913Gln polymorphism of SLC12A3 gene may predict the risk of increase of albuminuria in patients with T2DM in Chinese population.

DN/ESRD In this study it was suggested that the SLC12A3-Arg913GIn variation is associated with a high risk of DN/ESRD in Chinese T2DM patients undergoing haemodialysis.

$\begin{array}{llll}\text { Zhang } & \begin{array}{l}\text { Case- } \\ \text { et al }[48]\end{array} \\ \text { control } & \text { Chinese } & 221 & 151 \\ & & & \end{array}$
Female $n=84$; Male $n=137$; Duration of diabetes $\pm \mathrm{SD}$ (years) $=17.7 \pm 0.6$; $\mathrm{HbA} 1 \mathrm{C}$ $(\%) \pm \mathrm{SD}=7.1 \pm 0.2 ; \mathrm{FBS}(\mathrm{mg} / \mathrm{dL}) \pm \mathrm{SD}=$ $147.7 \pm 5.4$.

(1)

Abbreviations: $A C R$ albumin-creatinine ratio, DN diabetic nephropathy, ESRD End-Stage Renal Disease, FBS Fasting blood sugar, S-Cr Serum creatinine, SD Standar Desviation, SLC12A3 gene solute carrier family 12 member 3-gene, T2DM type 2 diabetes mellitus

excretion. Additionally, these studies reported that the minor allele 913Gln in the SLC12A3 gene could have a protective genetic effect against the development and/or progression of diabetic nephropathy for these populations $(p<0.01)[43,45]$. Nevertheless, Tanaka et al [23] also analyzed Japanese individuals and found that substitution of Arg913 to Gln in the SLC12A3 gene could reduce the risk of developing diabetic nephropathy [23]. On the other hand, Yadav et al [44] and Ng et al [24] analyzed Indians and American Caucasians populations, respectively. In both studies none polymorphisms in SLC12A3 gene (including the Arg913Gln variation) 
were associated with diabetic nephropathy [24, 44]. Additionally, Yadav and colleagues found significant differences in genotype and allelic frequency in the SLC12A3 gene between diabetic subjects and controls $(P<0.03$, 44]. The number of cases (sample size) for studies that associated the SLC12A3 gene with diabetic nephropathy in T2DM ranged from 71 to 583 .

\section{SLC12A3 gene in GS-individuals with diabetic nephropathy}

Four studies that analyze the SLC12A3 gene in GSindividuals were found (see Table 2). Ren et al [33], Tseng et al [35] and Yuan et al [32] analyzed an Asian population, in which abnormalities in glucose metabolism (that is, high glycemia levels) and insulin secretion in GS-individuals were reported. Hence, homeostasis model assessment of insulin resistance in these patients was significantly higher ( $p<0.05$ for these studies) [32, $33,35]$. Additionally, Tseng and colleagues indicated that GS-individuals may be at increased risk for the development of T2DM and diabetic nephropathy [35]. Moreover, Balavoine et al [49] analyzed a French population, in which also an increased susceptibility to glucose intolerance was associated with renal failure in GS heterozygous patients. Likewise, Balavoine and colleagues found that GS was more severe in individuals with heterozygous mutant alleles than in those with homozygous mutant alleles in SLC12A3 gene [49]. The number of cases (sample size) for studies that associated the SLC12A3 gene with diabetic nephropathy in GS ranged from 16 to 117 .

\section{Discussion}

In this systematic review, the association of the Arg913Gln variation of SLC12A3 gene with diabetic nephropathy in individuals with T2DM and GS was explored. In an important way, it should be noted that a meta-analysis has studied the SLC12A3 gene in association with diabetic nephropathy in T2DM [43]. However, this study only included a small group of studies (four studies) in its review, and did not include GSindividuals with diabetic nephropathy and/or T2DM [43]. In regard to this variation of SLC12A3 gene in T2DM-individuals with diabetic nephropathy, this systematic review found a genetic association in most the studies included [42, 43, 45-48]. However, two of these studies indicated that others genetic variants in this gene could have a protective effect in this disease [43, 45], which also coincides with the findings by Tanaka et al [23], who indicated that SLC12A3 -Arg913Gln gene variation could reduce the risk to develop diabetic nephropathy in T2DM [23]. A possible reason for this discrepancy in these results may be related to a wide variety of genetic factors are involved in diabetic nephropathy in a complex form, in which these variants in the SLC12A3 gene may be present in regulating regions,

Table 2 Evidence from studies involving the Gitelman's Syndrome individuals in risk of nephropathy and T2DM

\begin{tabular}{|c|c|c|c|c|c|c|c|}
\hline \multirow{2}{*}{$\begin{array}{l}\text { Author } \\
\text { (year) }\end{array}$} & \multirow{2}{*}{$\begin{array}{l}\text { Study } \\
\text { design }\end{array}$} & \multirow[t]{2}{*}{ Population } & \multicolumn{2}{|c|}{ N Sample } & \multirow{2}{*}{$\begin{array}{l}\text { Characteristics of GS individuals with risk } \\
\text { of nephropathy and T2DM }\end{array}$} & \multirow{2}{*}{$\begin{array}{l}\text { Major } \\
\text { diagnosis }\end{array}$} & \multirow{2}{*}{$\begin{array}{l}\text { Main results of association in GS individuals } \\
\text { with risk of nephropathy and T2DM. }\end{array}$} \\
\hline & & & Cases & Controls & & & \\
\hline $\begin{array}{l}\text { Yuan et al } \\
{[32]} \\
(2017)\end{array}$ & $\begin{array}{l}\text { Case- } \\
\text { control }\end{array}$ & Chinese & 28 & 20 & $\begin{array}{l}\text { AUC glucose }(\mathrm{mmol} \cdot \mathrm{h} / \mathrm{L}) \pm S D=17.4 \pm \\
5.1 ; \mathrm{AUC} \text { insulin }(\mu \mathrm{U} \cdot \mathrm{h} / \mathrm{mL} \pm \mathrm{SD}= \\
221.5 \pm 128.1 ; \mathrm{ISSI} \pm \mathrm{SD}=81,389 \pm 34,680 \\
\mathrm{QUICKI} \pm \mathrm{SD}=0.6 \pm 0.1 ;\end{array}$ & GS/DN & $\begin{array}{l}\text { This study reported abnormalities in glucose } \\
\text { metabolism and insulin secretion in GS } \\
\text { patients. It was also observed that the areas } \\
\text { under the serum glucose curves were higher } \\
\text { in the GS patients than those in the healthy } \\
\text { controls }(p=0.02) \text {. }\end{array}$ \\
\hline
\end{tabular}

Tseng Follow- Taiwanese $117 \quad$ NA

et al [35] up

(2012)

Ren et al Case- Chinese $16 \quad 12$

[33] control

(2013)

$\begin{array}{llll}\begin{array}{l}\text { Balavoine } \\ \text { et al [49] }\end{array} \text { follow- French } & 15 \quad 5\end{array}$

(2011)
Female $n=47$; Male $n=70$; Duration of $\mathrm{GS} / \mathrm{DN}$ diabetes $\pm \mathrm{SD}$ (years) $=23 \pm 3$; FBS \pm $\mathrm{SD}=131-225 ; \mathrm{S}-\mathrm{Cr}(\mathrm{mg} / \mathrm{dl}) \pm \mathrm{SD}=2.2 \pm 1.0$

AUC glucose $(\mathrm{mEq} \cdot \mathrm{h} / \mathrm{L})=16.1(\mathrm{IQR}$ 12.5-25.4); AUC insulin $(\mu \mathrm{U} \cdot \mathrm{h} / \mathrm{mL})=$ 81.0 (IQR 58.9-138).

\footnotetext{
Age (years) $\pm \mathrm{SD}=35 \pm 15 ; \mathrm{BMI}(\mathrm{kg} / \mathrm{m} 2) \pm \mathrm{GS} / \mathrm{DN}$ $\mathrm{SD}=24.3 \pm 6.7 ; \mathrm{T} 2 \mathrm{DM}=20 \%(3 / 15) ; \mathrm{S} \mathrm{Cr}$ $(\mathrm{mg} / \mathrm{l}) \pm \mathrm{SD}=8.2 \pm 1.1$.
}

GS/DN This study found that GS patients showed a higher glucose level compared with control group ( $p<0.05$ ).Also, Ren and colleagues observed that GS patients showed a delay of insulin secretion peak which was observed 120 min after a glucose load.

In this study was found an increased susceptibility to glucose intolerance in GS heterozygous patients. Additionally, Balavoine and colleagues confirmed the presence of mutations of the SLC12A3 gene in $80 \%$ of cases.

Abbreviations: AUC area under curve, CKD chronic kidney disease, DN diabetic nephropathy, FBS Fasting blood sugar, GS Gitelman's syndrome, IQR interquartile range, ISSI insulin secretion-sensitivity index, NA not applicable, SD standard desviation, SLC12A3 gene solute carrier family 12 member 3-gene, T2DM type 2 diabetes mellitus, QUICKI quantitative insulin sensitivity check index 
such as promoter, intron sequences or $5^{\prime}$ and $3^{\prime}$ noncoding regions, and the effect of such polymorphisms may not have been detected in the relatively small populations of T2DM-individuals with diabetic nephropathy. Regarding the SLC12A3 gene in GS-individuals with diabetic nephropathy, when the results of these studies were analyzed globally [32, 33, 35, 49], it was observed an increased susceptibility to glucose intolerance as well as abnormalities in insulin secretion, which were associated with renal failure within this group of patients. The assumption that Gitelman syndrome is caused by an alteration in the thiazide-sensitive sodium-chloride cotransporter in the distal convoluted tubule has recently been proven by the identification of several mutations (mainly amino acid substitutions) in the SLC12A3 gene, where also a large number of deep intronic mutations could be linked with the development and/or progression of diabetic nephropathy [32, 35]. Therefore, it is likely that the majority of these alterations are indeed harmful mutations and not innocuous polymorphisms linked with kidney disease. Likewise, phenotypic variability in terms of biochemical alterations (such as hypomagnesemia and hypokalemia), could also play an important role in the pathogenesis of DN in GSindividuals, in which this heterogeneity has even been described in case reports within GS families with identical genetic mutations $[34,50]$. Unfortunately, the biochemical mechanisms by which magnesium and potassium deficiency induces or worsens T2DM in GSindividuals are not well understood, but it is thought that these electrolytic alterations may induce altered cellular glucose transport, defective post receptor insulin signaling, impaired secretion of biologically active insulin as well as altered insulin-insulin receptor interactions $[51,52]$. Also, it is interesting that the induction of magnesium and potassium deficiency has been shown to reduce insulin sensitivity in subjects without T2DM, whereas that supplementation of these electrolytes during relatively long periods has been shown to improve glucose handling in elderly subjects without T2DM [53, 54]. Additionally, it has been indicated that complications of T2DM (e.g. diabetic nephropathy, retinopathy, neuropathy, and foot ulcerations) are more severe in the presence of chronic hypomagnesaemia of any cause [51]. The present study also has some limitations inherent to the studies included. For instance, only studies published in journals were included in this review, since studies with negative results are often not published, resulting to an overestimation of genetic implications. Also, the design and the small number of studies included in this systematic review limit the ability to make causal inferences; since the studies included in this review were not clustered in terms of ethnicity. Hence, failure to account for ethnicity- specific interactions between genetic polymorphisms and environmental factors could also contribute to the pattern of results observed in individuals with diabetic nephropathy and/or end-stage renal disease. Nevertheless, the potential limitation of the present study is the substantial methodological heterogeneity of the findings obtained in this systematic review.

\section{Conclusions}

The present systematic review provides evidence to support that the Arg913Gln variation of SLC12A3 gene is associated with the diabetic nephropathy in individuals with T2DM and GS. Because most of the individuals included in this research belonged to Asian populations, the findings of this systematic review need to be confirmed and replicated in other ethnicities worldwide with heterozygous carriers. Moreover, the recommendation for future GWAS as strategy for unravelling genetic complexity on diabetic nephropathy outcomes in individuals with T2DM and GS. Thus, the findings in these studies could be supportive in replicating existing evidence and in revealing genuine genetic effects to confirm the role of the polymorphisms of candidate genes linked with end-stage renal disease with an observable trait.

\section{Supplementary information}

Supplementary information accompanies this paper at https://doi.org/10. 1186/s12882-019-1590-9.

Additional file 1. Search strategy terms and results.

Additional file 2. PRISMA Checklist.

\section{Abbreviations}

CCD: Cortical collecting duct; CLCNKB: Chloride voltage-gated channel Kb; CNT: Connecting tubule; DCT: Distal convoluted tubule; DN: Diabetic nephropathy; eGFR: estimated glomerular filtration rate; ENaC: Epithelial sodium channel; ESRD: End-stage renal disease; GS: Gitelman's syndrome; GWAS: Genome-wide association studies; NCC: thiazide sensitive $\mathrm{Na}-\mathrm{Cl}$ cotransporter; ROMK: Renal outer medullary potassium channel;

SLC12A3: Solute carrier family 12 member 3; T2DM: Type 2 diabetes mellitus

\section{Acknowledgments}

The authors acknowledge Dr. Julio Cesar Dominguez Ceballos and Dr. Raymundo Maria Carrera for her contribution to the work described here and her review of the manuscript.

Data sharing statement

No additional data are available.

\section{Authors' contributions}

E.D.C. and J.D.G. conducted the literature search and wrote the first draft, as well as the revised version of the review. C.J.G and V.M.G. designed the images presented in this review. F.J.R.G., J.G.T.J., C.P.P. and S.J.M commented on the manuscript drafts. All authors read and approved the final manuscript.

Funding

Not applicable. 


\section{Availability of data and materials}

All data generated or analysed during this systematic review are included in the published article. (Additional file 1 \& Additional file 2).

\section{Ethics approval and consent to participate} Not applicable.

\section{Consent for publication}

Not applicable.

\section{Competing interests}

The authors declare that they have no com interest.

\section{Author details}

'División Académica Multidisciplinaria de Comalcalco, Universidad Juárez Autónoma de Tabasco, C. P. 86650 Comalcalco, Tabasco, Mexico. ²Secretaría de Salud, Hospital General de Comalcalco, Departamento de Laboratorio de Análisis Clínicos, C.P. 86300 Comalcalco, Tabasco, Mexico. ${ }^{3}$ División Académica de Ciencias de la Salud, Universidad Juárez Autónoma de Tabasco, C.P. 86100 Villahermosa, Tabasco, Mexico. ${ }^{4}$ Instituto Nacional de Medicina Genómica (INMEGEN), Laboratorio Genómica del Cáncer, Periférico Sur No. 4809, Col. Arenal Tepepan, Deleg. Tlalpan, C.P. 14610 Ciudad de México, Mexico. ${ }^{5}$ Universidades para el Bienestar Benito Juárez García, Medicina Integral y Salud Comunitaria, Juan R. Escudero, Guerrero, C.P. 39940, Mexico

\section{Received: 24 January 2018 Accepted: 14 October 2019}

\section{Published online: 28 October 2019}

\section{References}

1. Keane WF, Brenner BM, de Zeeuw D, Grunfeld JP, McGill J, Mitch WE, Ribeiro AB, Shahinfar S, Simpson RL, Snapinn SM, et al. The risk of developing end-stage renal disease in patients with type 2 diabetes and nephropathy: the RENAAL study. Kidney Int. 2003;63(4):1499-507.

2. Rossing P. Diabetic nephropathy: worldwide epidemic and effects of current treatment on natural history. Curr Diab Rep. 2006:6(6):479-83.

3. Schieppati A, Remuzzi G. Chronic renal diseases as a public health problem: epidemiology, social, and economic implications. Kidney Int Suppl. 2005;98:S7-s10

4. Bener A, Al-Laftah F, Al-Hamaq AO, Daghash M, Abdullatef WK. A study of diabetes complications in an endogamous population: an emerging public health burden. Diabetes Metab Syndr. 2014;8(2):108-14.

5. Zhou Z, Chaudhari $P$, Yang $H$, Fang $A P$, Zhao J, Law EH, Wu EQ, Jiang $R$, Seifeldin R. Healthcare resource use, costs, and disease progression associated with diabetic nephropathy in adults with type 2 diabetes: a retrospective observational study. Diabetes Ther. 2017;8(3):555-71.

6. Coresh J, Turin TC, Matsushita K, Sang Y, Ballew SH, Appel L, Arima H, Chadban SJ, Cirillo M, Djurdjev O, et al. Decline in estimated glomerular filtration rate and subsequent risk of end-stage renal disease and mortality. Jama. 2014;311(24):2518-31.

7. Badve SV, Palmer SC, Hawley CM, Pascoe EM, Strippoli GF, Johnson DW. Glomerular filtration rate decline as a surrogate end point in kidney disease progression trials. Nephrol Dial Transplant. 2016;31(9):1425-36.

8. Low S, Lim SC, Yeoh LY, Liu YL, Liu JJ, Fun S, Su C, Zhang X, Subramaniam T, Sum CF. Effect of long-term glycemic variability on estimated glomerular filtration rate decline among patients with type 2 diabetes mellitus: insights from the diabetic nephropathy cohort in Singapore. J Diabetes. 2016.

9. Carrero JJ, Grams ME, Sang Y, Arnlov J, Gasparini A, Matsushita K, Qureshi AR, Evans M, Barany P, Lindholm B, et al. Albuminuria changes are associated with subsequent risk of end-stage renal disease and mortality. Kidney Int. 2017;91(1):244-51.

10. Bakris GL, Agarwal R, Chan JC, Cooper ME, Gansevoort RT, Haller H, Remuzzi G, Rossing P, Schmieder RE, Nowack C, et al. Effect of Finerenone on albuminuria in patients with diabetic nephropathy: a randomized clinical trial. Jama. 2015:314(9):884-94.

11. Lipkowitz MS, Freedman BI, Langefeld CD, Comeau ME, Bowden DW, Kao WH, Astor BC, Bottinger EP, lyengar SK, Klotman PE, et al. Apolipoprotein L1 gene variants associate with hypertension-attributed nephropathy and the rate of kidney function decline in African Americans. Kidney Int. 2013;83(1):114-20.
12. Sternlicht $H$, Bakris GL. Management of Hypertension in diabetic nephropathy: how Low should we go? Blood Purif. 2016;41(1-3):139-43.

13. Eid AA, Ford BM, Bhandary B, de Cassia CR, Block K, Barnes JL, Gorin Y, Choudhury GG, Abboud HE. Mammalian target of rapamycin regulates Nox4-mediated podocyte depletion in diabetic renal injury. Diabetes. 2013; 62(8):2935-47.

14. Zhou L, Liu Y. Wnt/beta-catenin signalling and podocyte dysfunction in proteinuric kidney disease. Nat Rev Nephrol. 2015;11(9):535-45.

15. Marshall CB. Rethinking glomerular basement membrane thickening in diabetic nephropathy: adaptive or pathogenic? Am J Physiol Renal Physiol. 2016;311(5):F831-f843.

16. Ewens KG, George RA, Sharma K, Ziyadeh FN, Spielman RS. Assessment of 115 candidate genes for diabetic nephropathy by transmission/ disequilibrium test. Diabetes. 2005;54(11):3305-18.

17. Abrass CK. Diabetic nephropathy. Mechanisms of mesangial matrix expansion. West J Med. 1995;162(4):318-21.

18. Kriz W, Lowen J, Federico G, van den Born J, Grone E, Grone HJ. Accumulation of worn-out GBM material substantially contributes to mesangial matrix expansion in diabetic nephropathy. Am J Physiol Renal Physiol. 2017;312(6):F1101-f1111.

19. Bai X, Hou X, Tian J, Geng J, Li X. CDK5 promotes renal tubulointerstitial fibrosis in diabetic nephropathy via ERK1/2/PPARgamma pathway. Oncotarget. 2016;7(24):36510-28.

20. Sowers KM, Habibi J, Hayden MR. Diabetic nephropathy and tubulointerstitial fibrosis in cardiometabolic syndrome and type 2 diabetes mellitus. J Cardiometab Syndr. 2007;2(2):143-8.

21. Moeller MJ, Smeets B. Role of parietal epithelial cells in kidney injury: the case of rapidly progressing glomerulonephritis and focal and segmental glomerulosclerosis. Nephron Exp Nephrol. 2014;126(2):97.

22. Wang $M$, Zhang $X$, Song $X$, Zou $X$, Wu W, Wang $Y$, Lin B, Li R, Hu F, Zhao H. Nodular glomerulosclerosis and renin angiotensin system in Chinese patients with type 2 diabetes. Mol Cell Endocrinol. 2016:427:92-100.

23. Tanaka N, Babazono T, Saito S, Sekine A, Tsunoda T, Haneda M, Tanaka Y, Fujioka T, Kaku K, Kawamori R, et al. Association of solute carrier family 12 (sodium/chloride) member 3 with diabetic nephropathy, identified by genome-wide analyses of single nucleotide polymorphisms. Diabetes. 2003; 52(11):2848-53.

24. Ng DP, Nurbaya S, Choo S, Koh D, Chia KS, Krolewski AS. Genetic variation at the SLC12A3 locus is unlikely to explain risk for advanced diabetic nephropathy in Caucasians with type 2 diabetes. Nephrol Dial Transplant. 2008;23(7):2260-4

25. Shimazaki A, Kawamura Y, Kanazawa A, Sekine A, Saito S, Tsunoda T, Koya D, Babazono T, Tanaka Y, Matsuda M, et al. Genetic variations in the gene encoding ELMO1 are associated with susceptibility to diabetic nephropathy. Diabetes. 2005:54(4):1171-8.

26. Mastroianni N, De Fusco M, Zollo M, Arrigo G, Zuffardi O, Bettinelli A, Ballabio A, Casari G. Molecular cloning, expression pattern, and chromosomal localization of the human $\mathrm{Na}$-cl thiazide-sensitive cotransporter (SLC12A3). Genomics. 1996:35(3):486-93.

27. Gamba G. The thiazide-sensitive Na+-cl-cotransporter: molecular biology, functional properties, and regulation by WNKs. Am J Physiol Renal Physiol. 2009;297(4):F838-48

28. Hebert SC. Roles of Na-K-2Cl and Na-Cl cotransporters and ROMK potassium channels in urinary concentrating mechanism. Am J Phys. 1998;275(3 Pt 2): F325-7.

29. Gamba G. Molecular biology of distal nephron sodium transport mechanisms. Kidney Int. 1999;56(4):1606-22.

30. Azak A, Huddam B, Kocak G, Ortabozkoyun L, Uzel M, Duranay M. Gitelman syndrome complicated with dysglycemia. Acta Diabetol. 2011:48(3):249-50.

31. Knoers NV, Devuyst O, Kamsteeg EJ. Clinical utility gene card for: Gitelman syndrome. Eur J Hum Genet. 2011;19(8). https://doi.org/10.1038/ejhg.2011.14.

32. Yuan $T$, Jiang L, Chen C, Peng X, Nie M, Li X, Xing X, Li X, Chen L. Glucose tolerance and insulin responsiveness in Gitelman syndrome patients. Endocrine connections. 2017:6(4):243-52.

33. Ren H, Qin L, Wang W, Ma J, Zhang W, Shen PY, Shi H, Li X, Chen N. Abnormal glucose metabolism and insulin sensitivity in Chinese patients with Gitelman syndrome. Am J Nephrol. 2013;37(2):152-7.

34. Subasinghe $C J$, Sirisena ND, Herath C, Berge KE, Leren TP, Bulugahapitiya U, Dissanayake VHW. Novel mutation in the SLC12A3 gene in a Sri Lankan family with Gitelman syndrome \& coexistent diabetes: a case report. BMC Nephrol. 2017;18(1):140. 
35. Tseng MH, Yang SS, Hsu YJ, Fang YW, Wu CJ, Tsai JD, Hwang DY, Lin SH. Genotype, phenotype, and follow-up in Taiwanese patients with salt-losing tubulopathy associated with SLC12A3 mutation. J Clin Endocrinol Metab. 2012:97(8):E1478-82

36. Colussi G, Rombola G, Brunati C, De Ferrari ME. Abnormal reabsorption of $\mathrm{Na}+/ \mathrm{Cl}$ - by the thiazide-inhibitable transporter of the distal convoluted tubule in Gitelman's syndrome. Am J Nephrol. 1997;17(2):103-11.

37. Seyberth HW, Schlingmann KP. Bartter- and Gitelman-like syndromes: salt-losing tubulopathies with loop or DCT defects. Pediatr Nephrol. 2011;26(10):1789-802.

38. Knoers NV, Levtchenko EN. Gitelman syndrome. Orphanet J Rare Dis. 2008;3:22.

39. De Jong JC, Van Der Vliet WA, Van Den Heuvel LP, Willems PH, Knoers NV, Bindels RJ. Functional expression of mutations in the human $\mathrm{NaCl}$ cotransporter: evidence for impaired routing mechanisms in Gitelman's syndrome. J Am Soc Nephrol. 2002;13(6):1442-8.

40. Cruz DN, Shaer AJ, Bia MJ, Lifton RP, Simon DB. Gitelman's syndrome revisited: an evaluation of symptoms and health-related quality of life. Kidney Int. 2001;59(2):710-7.

41. Moher D, Liberati A, Tetzlaff J, Altman DG. Preferred reporting items for systematic reviews and meta-analyses: the PRISMA statement. Int I Surg (London, England). 2010;8(5):336-41.

42. Kim JH, Shin HD, Park BL, Moon MK, Cho YM, Hwang YH, Oh KW, Kim SY, Lee HK, Ahn C, et al. SLC12A3 (solute carrier family 12 member [sodium/ chloride] 3) polymorphisms are associated with end-stage renal disease in diabetic nephropathy. Diabetes. 2006;55(3):843-8.

43. Abu Seman N, He B, Ojala JR, Wan Mohamud WN, Ostenson CG, Brismar K, Gu HF. Genetic and biological effects of sodium-chloride cotransporter (SLC12A3) in diabetic nephropathy. Am J Nephrol. 2014;40(5):408-16.

44. Yadav AK, Kumar V, Dutta P, Bhansali A, Jha V. Variations in CCR5, but not HFE, ELMO1, or SLC12A3, are associated with susceptibility to kidney disease in north Indian individuals with type 2 diabetes. J Diabetes. 2014;6(6):547-55.

45. Nishiyama K, Tanaka Y, Nakajima K, Mokubo A, Atsumi Y, Matsuoka K, Watada H, Hirose T, Nomiyama T, Maeda S, et al. Polymorphism of the solute carrier family 12 (sodium/chloride transporters) member 3, SLC12A3, gene at exon 23 (+78G/a: Arg913GIn) is associated with elevation of urinary albumin excretion in Japanese patients with type 2 diabetes: a 10-year longitudinal study. Diabetologia. 2005;48(7):1335-8.

46. Bodhini D, Chidambaram M, Liju S, Revathi B, Laasya D, Sathish N, Kanthimathi S, Ghosh S, Anjana RM, Mohan V, et al. Association of rs11643718 SLC12A3 and rs741301 ELMO1 variants with diabetic nephropathy in south Indian population. Ann Hum Genet. 2016;80(6):336-41.

47. Zhao W, Liu L, Zheng T, Li M, Wang N, Wang F. Relationship between SLCI2A3 gene Arg913Gin polymorphism and type 2 diabetic nephropathy in Han population of Shanghai. J Shanghai Jiaotong University (Med Sci). 2009:29(7):828-33.

48. Zhang R, Zhuang L, Li M, Zhang J, Zhao W, Ge X, Chen Y, Wang F, Wang N, Bao $Y$ et al: Arg913Gln of SLC12A3 gene promotes development and progression of end-stage renal disease in Chinese type 2 diabetes mellitus. 2017.

49. Balavoine AS, Bataille P, Vanhille P, Azar R, Noel C, Asseman P, Soudan B, Wemeau JL, Vantyghem MC. Phenotype-genotype correlation and followup in adult patients with hypokalaemia of renal origin suggesting Gitelman syndrome. Eur J Endocrinol. 2011;165(4):665-73.

50. Gil-Pena H, Coto E, Santos F, Espino M, Cea Crespo JM, Chantzopoulos G, Komianou F, Gomez J, Alonso B, Iglesias S et al: A new SLC12A3 founder mutation (p.Val647Met) in Gitelman's syndrome patients of Roma ancestry. Nefrologia : publicacion oficial de la Sociedad Espanola Nefrologia 2017.

51. Pham PC, Pham PM, Pham SV, Miller JM, Pham PT. Hypomagnesemia in patients with type 2 diabetes. Clin J Am Soc Nephrol. 2007;2(2):366-73.

52. Dronavalli S, Bakris GL. Mechanistic insights into diuretic-induced insulin resistance. Hypertension. 2008:52(6):1009-11.

53. Nadler JL, Buchanan T, Natarajan R, Antonipillai I, Bergman R, Rude R. Magnesium deficiency produces insulin resistance and increased thromboxane synthesis. Hypertension. 1993;21 (6 Pt 2):1024-9.

54. Paolisso G, Sgambato S, Gambardella A, Pizza G, Tesauro P, Varricchio M, D'Onofrio $F$. Daily magnesium supplements improve glucose handling in elderly subjects. Am J Clin Nutr. 1992;55(6):1161-7.

\section{Publisher's Note}

Springer Nature remains neutral with regard to jurisdictional claims in published maps and institutional affiliations.

Ready to submit your research? Choose BMC and benefit from:
- fast, convenient online submission
- thorough peer review by experienced researchers in your field
- rapid publication on acceptance
- support for research data, including large and complex data types
- gold Open Access which fosters wider collaboration and increased citations
- maximum visibility for your research: over 100M website views per year
At BMC, research is always in progress.
Learn more biomedcentral.com/submissions

